\title{
Javanese Speech Politeness in Expressive Speech Act of Women Leader Utterance in Ponorogo Regency
}

\author{
Diyah Atiek Mustikawati \\ \{diyahmustikawati08@yahoo.co.id ${ }^{1}$ \} \\ Universitas Muhammadiyah Ponorogo ${ }^{1}$
}

\begin{abstract}
This study revealed Javanese speech politeness in expressive speech act of women leader utterance in Ponorogo. Javanese speech politeness holds important role in the realization of Javanese speech act. There are three levels of Javanese speech politeness in this research that is very polite $(\mathrm{KI})$, polite $(\mathrm{KM})$, and impolite $(\mathrm{Ng})$. This research used pragmatic qualitative approach, this study examined women leader in 8 urban and rural area in Ponorogo. The result showed that expressive speech act consists of thanking $49 \%$, greeting $27 \%$, and apologizing $24 \%$. The Javanese speech politeness in expressive speech act of women leader found in three language situations that is service, event, and meeting language situation. Three of kinds expressive speech acts mostly found in event language situation. Both in apologizing and greeting there is no Javanese speech politeness of expressive act in service language situation. Very polite and polite are high and impolite only found one in service language situation of thanking. The Javanese speech politeness influenced the use of expressive speech act in accordance with context or language situation. Suggestions are made to compare or contrast with utterance in any field of Javanese speech politeness.
\end{abstract}

Keywords: Javanese speech politeness, expressive speech act

\section{Introduction}

To have command of something in mind, grasp what is said, and produce a signal with an intended semantic interpretation, language associates sound and meaning in a specific way [4]. On the other hand, language is a learned vocal system for conveying meaning based on human life experiences. People use language for a variety of reasons, including expressing their thoughts and feelings, conveying claims and arguments, and requesting information. Meaning is established not by the formal qualities of words and constructions, but by how utterances are used and how they connect to the context in which they are produced, according to this theory [28].

On the other hand, language serves a social role by allowing people to connect. People appear to find it impossible to communicate with others in their daily conversation without language. Therefore, speakers should be able to choose acceptable conversation methods in order to keep the conversation going. Cultural conventions, which are founded on a community's values, frequently influence politeness methods. On the other hand, every community has its own normative notion of politeness, which is not the same for all interlocutors, settings, or cultures. For example, in Javanese culture [7].

Furthermore, according to Leech [13], the study of meaning in connection to speech situations or language usage is known as pragmatics. Pragmatics is a discipline with the ability 
to investigate social concerns. It's a research project that spans linguistics and other fields [1]. Furthermore, pragmatics is a field of linguistics that investigates the structure of language from the outside, that is, how the language unit is utilized in communication, and thus it is a study of language that encompasses macro linguistics [9]. Furthermore, according to Cutting [5], pragmatics takes a socio-cultural approach to language usage, exploring how the social distance between speakers influences how principles of social behavior are represented. It refers to the unspoken rules of speech that speakers adhere to in order to collaborate and be socially acceptable to one another. It may be stated that pragmatics is the study of meaning and linguistic units used in communication, and how they connect to the context, such as the age, status, position, relationship, social limitations, and gender of the addressee in Javanese.

Meanwhile, politeness is a pragmatic phenomenon. Politeness operates in the use of language in real life [1]. Based on Cutting [5], politeness is defined by the function and intended social meaning of words, not by their appearance. Then, according to Watts [30], politeness is something we must learn and be socialized into, and no generation has been short of teachers and handbooks on etiquette and "proper behavior" to assist us in developing polite abilities. Brown \& Levinson [3] states that politeness' primary function is to prevent potential conflict between interacting people. Furthermore, politeness is expressed in different ways and has diverse meanings depending on the culture [7].

Javanese politeness is influenced by the existence of culture. It cannot be separated from the concept of Javanese culture. Tata krama, andhap-ashor, and tanggap ing sasmita are the three. It refers to a person's speaking style, lowering oneself while exalting others, and the ability to decipher concealed meaning. Tata krama, as stated in Pragmatic Tata, is the organization of Bahasa or speech levels [27]. Besides, In Javanese it is known as unggah ungguh where people should know the context and situation and to whom they speak [16].

According to Poedjosoedarmo [20] and Errington [6], Ngoko (Ng) is the lowest level of speech, Krama Madya (KM) is the intermediate level, and Krama Inggil (KI) is the highest level. Each level represents a different level of civility. $\mathrm{Ng}$ is the rudest, whereas $\mathrm{KI}$ is the nicest. It can be described in word 'you'.

- Kowe $(\mathrm{Ng})$

- Sampeyan (KM)

- Panjenengan (KI)

Some non-linguistic criteria, such as social standing, age, and distance from the subject, influence the choice of these levels [26]. Meanwhile, Brown \& Levinson [3] identify social distance, relative authority, and the weight of imposition of the utterance as elements that influence the usage of politeness. Politeness tactics are linked to the degree of explicitness and directness of speech actions, as well as the verb used in the speech act, all of which influence the participants' social distance and relative power [18].

Furthermore, in conversation people not only say something, but also, they do something with their word [2]. In conveying the meaning and purpose the speaker should describe certain maxim of conversation in order to cooperate and be socially acceptable to each other. The act done when say something means speech act. Speech act as a pragmatic phenomenon as well. The term of speech act is pioneered by the term of illocutionary force, what is done in uttering the words, the function of the words, the specific purpose that the speakers have in mind [5]. Specifically, Searle [24] classify speech act into five that is representative, commissive, directive, expressive, and declarative. This paper will be focusing on expressive speech act

People, being social beings, require communication with others, exchanging ideas, expressing feelings and emotions, and engagement to meet their requirements. The speaker's utterances are actions or behaviors that may include words that communicate their feelings [8]. 
According to Mufiah and Rahman [15], expressive acts express the speaker's feelings, including psychological states or assertions of pleasure, pain, likes, dislikes, joy, or sorrow. Furthermore, expressive speech acts communicate the speaker's feelings about the current state of affairs in a sincere manner and the social interaction between the speaker and the listener [23]. Then there's the category of expressive speech acts, which includes several diverse subcategories that have gotten little attention thus far [22]. If you're looking for a unique way to express yourself.

According to Searle [24], expressiveness can express a psychological state specified in the sincerity condition about a situation specified in the propositional content. The current paradigm of Thank, congratulate, apologize, condole, deplore, and welcome are examples of expressive verbs. Express, according to Cutting [5], are acts in which the words express the speaker's feelings, such as "apologizing," "praising," "congratulating," "deploring," and "regretting." Meanwhile, according to Kreidler [11], an expressive utterance arises from the current outcome of those activities or failures. As a result, expressive statements are retrospective and involve the speaker. Acknowledge, admit, confess, deny, and apologize are the most prevalent expressive verbs. According to Lanigan [12], the definition of expressive is to express the psychological state described in the sincerity condition concerning a situation specified in the propositional content. Thanks, congratulations, apologies, condolences, welcomes, greets, and applause are the paradigms of expressive.

In the topic of expressive speech acts, numerous studies have been conducted. In Hannah Montana Session 1, Handayani [8] highlights the usage of expressive speech acts. Mufiah and Rahman [15] examine Donald Trump's speech in terms of speech acts. In the literary dialogue The Perfect Husband, Seviyani \& Pujiati [25] exhibits expressive speech act. Royanti [23] performs an expressive speech act similar to that seen in La La Land's film. In the interaction of the Bahasa Indonesia learning process at MAN Kota Surakarta, Mulyono [16] demonstrates students' expressive politeness. In the story Dewaruci, Dalang Nartasabda's work, Heriwati [9] exhibits expressive speech act. In the pragmatically annotated SPICE Ireland corpus, Ronan [22] categorizes expressive speech activities. The expressive speech act utilized by Anies Rasyid Baswedan and Recep Tayyip Erdogan in response to the attacks in Christchurch, New Zealand, is revealed by Tamam et al [28]. Tauchid and Rukmini [29] examine expressive speech acts as seen on Wayne Rooney's Facebook page. Then, in New Moon, Mustofa et al. [17] show the male character's expressive speech act during romantic speech events.

Furthermore, certain studies on Javanese politeness, such as Sukarno [26] show that the politeness of Javanese reflects Javanese cultural concepts. Sukarno [27] highlights politeness tactics used by Javanese people while reacting to compliments. Then, according to Nuryantiningsih \& Pandanwangi [19], politeness and impoliteness in Javanese speech levels are shown. However, none of them focused on the politeness strategy in expressive communication in Javanese. This research specifically analyzes Javanese speech politeness strategy in expressive speech act of women leader utterance in Ponorogo Regency.

\section{Method}

Theoretically, this research uses a pragmatic approach, while methodology utilizes ethnography. Ethnographic research aims to describe cultural situations that are identified through conversation in certain events. Ethnography is a verbal description of the cultural situation that is learned or identified through the type of conversation that occurs. All cultural meanings created with these symbols are expressed directly in language. This research that 
studies about Javanese speech politeness in the realization of directive speech in which have their own implicature in certain language situation or context. Therefore, in order to capture the language in use or pragmatic, researcher needs detailed and in-depth description of data to reveal various uniqueness that can be scientifically accounted for (Miles and Huberman, 1994: 6-7). That is way, the type of research uses qualitative, because this research describes according to the purpose of the research.

The research data is in the form of utterances from women leaders in Ponorogo both rural area and urban area in social interactions collected by observation and interview techniques to informants. Data on women leader language collection amounts to 8 areas. Then, observation is a way to collect data by recording to the conversation of women leader used by Javanese women in Indonesia. In-depth interviews with informants are flexible, open, tightly structured, not in a formal setting, and carried out repeatedly. In ethnography, according to Spradley, this activity is called friendship conversation. In-depth interviews are methods of gathering information for research purposes by asking and answering questions face-to-face between interviewers and informants, with or without the use of interview guidelines, in situations where they have a long social life.

Data analysis refers to the Spradley model of analysis, which alludes to domain analysis, taxonomy, componential, and cultural themes. Domains refer to utterances used by women leader that focused on participants based on three language situations, they are meeting, service and event. From there, the linguistic features of utterances used by women leader become obvious. Taxonomy is data analysis based on groupings of categories of knowledge relevant to the theory. Component analysis aims to combine domain analysis with taxonomy into one part, the results which are subsequently interpreted by the researchers.

\section{Results and Discussions}

Woman leader in Ponorogo used three types of expressive speech act those are apologizing, thanking, and greeting show in Figure 1. Women leader utterances were divided into three language situation those are service language situation, event language situation, and meeting language situation. Each of them was collected from women leader utterances both in urban area and rural area. Meanwhile, there are three kinds of Javanese Politeness which the researcher used in this research. Those are very polite (Krama Inggil), Polite (Krama Madya), and Impolite (Ngoko). 


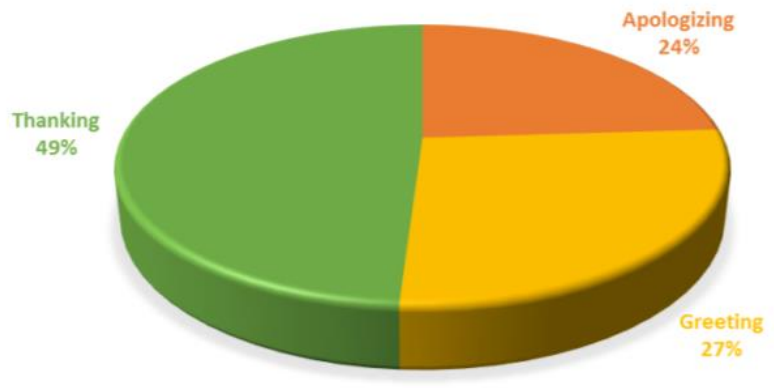

Fig. 1. Expressive speech act

Based on Figure 1, found that expressive speech acts uttered by women leader consisted of thanking $49 \%$, greeting $27 \%$, and apologizing 24\%. The most dominant is thanking and the least is apologizing. Those results were found from 94 expressive speech acts which divided: 23 of apologizing, 25 of greeting, and 46 of thanking. All of them were collected from women leader utterances in three language situations that is service, event, and meeting.

Thanking is a statement of gratitude from one person to another for anything that benefits them. Then there's apologizing, which is an expression of regret for a previous mistake. Greeting is an expression of delight to be a person on the occasion of good fortune expressed in the form of welcoming. According to Royanti [23], Thanking is an expressive act paradigm that was regarded to be one of global interpersonal communication to convey gratitude, appreciation, good faith, and so on. Thanking has a social role that entails acknowledging that one has benefited from the activities of another person. Apologize is a type of expressive speech act in which the speaker expresses sorrow or apology for something. The social function of apologizing is a value that is more important than ego in a relationship. Welcoming is a politeness act in which the speaker greets the listener in a nice or polite manner. It is a pleasure to be a person on the occasion of good fortune to exhibit empathic delight (an event). The friendly response of approving the other's participation to a place or event with enthusiasm joy is the social function of welcoming. By expressing delight at someone's presence we are attempting to make him or her feel at ease, or even to convey that his or her visit is seen as an honor.

Apologizing, on the other hand, is defined by Mustofa et al. [17] as saying sorry for someone. It's usually done after you've done something that has produced a problem. When meeting someone, a greeting is something you say. Thanking, on the other hand, is a form of expressive speaking act. When a speaker expresses his gratitude towards someone, this phrase is used. Furthermore, classification of Javanese speech politeness in three language situations of each expressive speech acts are as follow Figure 2. 


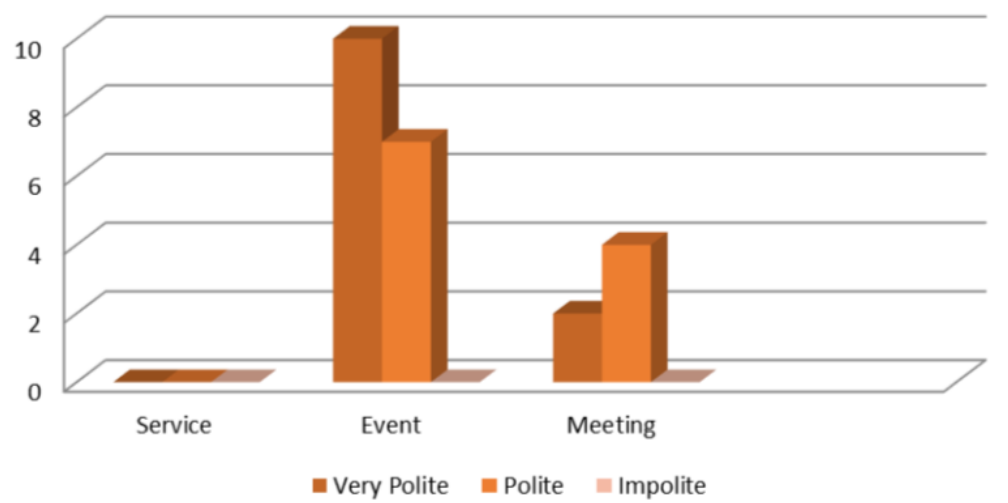

Fig. 2. Javanese speech politeness in apologizing expressive speech act

Firstly, Javanese speech politeness in apologizing expressive speech act. Based on Figure 2 , found that in service language situation, there is no Javanese speech politeness. Then, in event is excessively found rather than in meeting. Very polite found mostly in event language situation. Similarly, polite also mostly found in event language situation. Then, there is no impolite both in event and meeting language situations. Therefore, we can conclude that Javanese speech politeness of apologizing expressive speech acts are not found in service language situation and dominantly found in event language situation show on Figure 3. Then, impolite is not found both in event and meeting language situations.

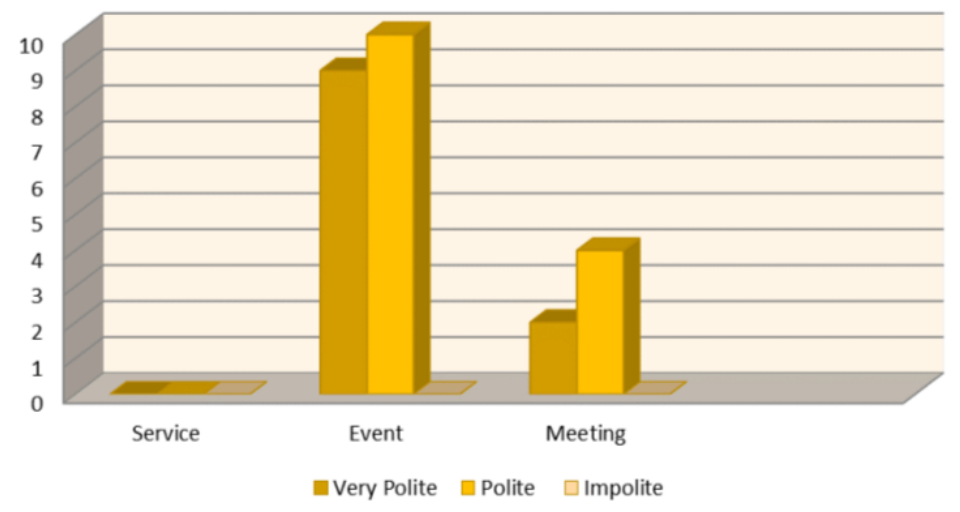

Fig. 3. Javanese Speech Politeness in Greeting Expressive Speech Act

Secondly, Javanese speech politeness in greeting expressive speech act. Based on Figure 3, the same result with apologizing, there is no Javanese speech politeness in service language situation. Then, the dominant Javanese speech politeness found in event language situation, and the least in meeting language situation. Therefore, we can conclude that Javanese speech politeness in greeting has the same result with apologizing. However, the difference with the previous kind of expressive speech act is that in Javanese speech politeness of greeting, in the 
dominant language situation, polite is higher than very polite. It means that polite is the highest among others. Javanese speech politeness in thanking expressive speech Act show in Figure 4.

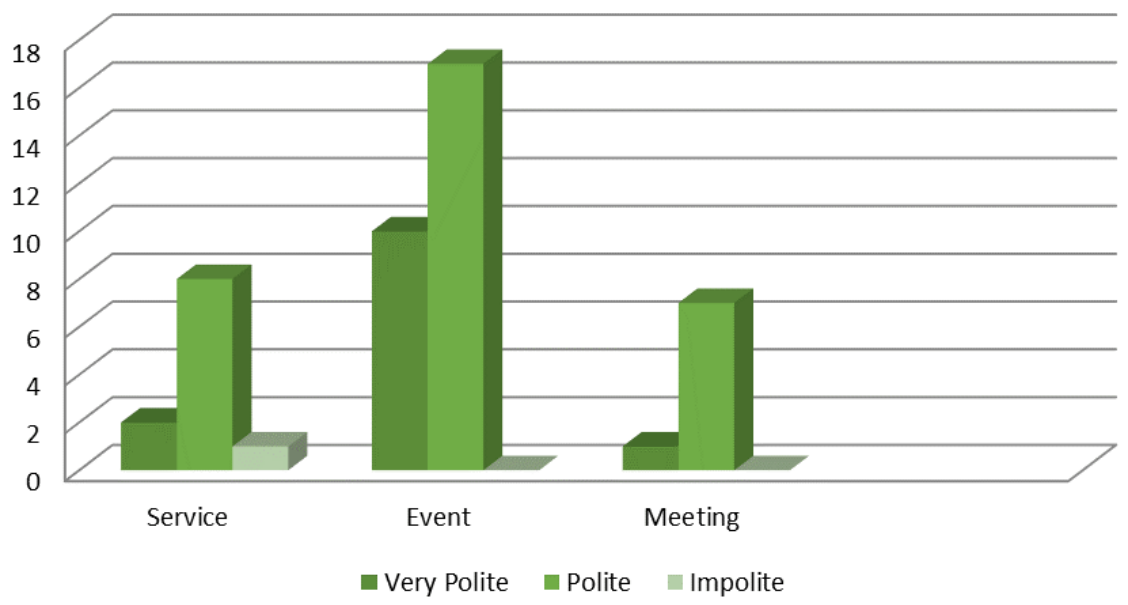

Fig. 4. Javanese Speech Politeness in Thanking Expressive Speech Act

Thirdly, Javanese speech politeness in thanking expressive speech act. Thanking is the most dominant among others expressive speech acts. According to the Figure 4, the most dominant Javanese speech politeness in thanking are found in event language situation. Polite is the highest among others. Then, very polite is found highest in event language situation. Impolite only found one in service language situation. Therefore, we can conclude that in thanking, the most dominant Javanese speech politeness in event language situation. Polite is the highest among others. Very polite mostly found in event language situation, and impolite only found one in service language situation, and not found in other language situation.

Furthermore, researcher would compare the current findings with the previous findings. We can conclude from three of that diagrams that apologizing, greeting, and thanking expressive speech act uttered by women leader were influenced by language situation that is service, event, and meeting. This in line with Rohali [21] revealed that politeness is a way of communicating using both language and non-language aspects in accordance with the context and situation of speech. It means factor that influence the levels of Javanese speech politeness is language situation. Meanwhile, non-linguistic criteria such as social standing, age, and distance from the topic influenced the choosing of these levels [26]. Meanwhile, Brown and Levinson [3] identified social distance, relative authority, and the weight of imposition of the utterance as elements that influence the usage of politeness. Furthermore, linguistic and non-linguistic aspects were present in the speakers' utterances in this investigation. The linguistic aspects are the shape and function of the speech, whereas the non-linguistic elements are the utterance strategy, implicature, and context of the utterance [14]. This statement supports the research result, women leader expressive speech act influences the implicature and influenced by context.

In this research, Javanese speech politeness are found in greeting expressive speech acts. In line with Junaidi [10] that asserts that the nature of expression, particularly greeting as one subcategory of acknowledgment, is utilized by speakers to show joy in meeting the audience 
and Then, the most dominant expressive speech act found in this research is thanking expressive speech act. However, Seviyani \& Pujiati [25] found that the function of speech expressed a lot is the function of apologizing (to express guilt). In this research, women leader used Javanese speech politeness of thanking a lot in event language situation in order to get face from the audience following language situation that is the formal situation. Supported with Tauchid and Rukmini [29] statement, Expressive speech activities such as complimenting, thanking, and boasting were most likely to elicit a high number of compliments from the audience.

Furthermore, according to Royanti [23], welcoming is a politeness gesture in which the speaker greets the listener nicely or kindly. It is a pleasure to be a person on the occasion of good fortune to exhibit empathic delight (an event). In line with this research result that in greeting expressive speech act, welcoming is mostly used. Then, both very polite and polite are high in event language situation.

In Javanese linguistic etiquette, discourse is deemed courteous if it is suitable and spoken at the proper level. Furthermore, a polite speech act is a speech delivered by the speaker to show respect for the listener [19]. In line with the result of this research, women leaders express thanking, apologizing, and greeting mostly found in event language situation in which formal situation. Very polite and polite are highly found. Then, impolite only found one in service language situation of thanking expressive speech act. It means, impolite is least in women leader Javanese speech politeness of expressive speech act.

\section{Conclusion}

Having done the analysis and discussion, it comes to the conclusion that there are three levels of Javanese speech politeness in women leader expressive speech act that is very polite $(\mathrm{KI})$, polite $(\mathrm{KM})$ and impolite $(\mathrm{Ng})$. Thanking expressive speech act dominantly found that is $49 \%, 27 \%$ of greeting, and $24 \%$ of apologizing. Javanese speech politeness found dominantly in event language situation in three kinds of expressive speech acts. Then, very polite and polite are high and impolite only found one in service language situation of thanking. Both in apologizing and greeting, there is no Javanese speech politeness of expressive speech acts in service language situation. The Javanese speech politeness influence the use of expressive speech act in accordance with context or language situation.

\section{References}

[1] Al-Bantany, Nabilah Fairuz. 2013. The Use of Commissive Speech Acts and Its Politeness Implication: A Case of Banten Gubernatorial Candidate Debate. Passage 2013, 1 (2), 21-34

[2] Austin, J. 1962. How To Do Things With Word. London: Oxford University Press

[3] Brown, P., \& Levinson, S. 1987. Politenss: Some universal in language usage. Cambridge: Cambridge University Press.

[4] Chomsky, N. 2006. Language and Mind Third Edition. New York: Cambridge University Press

[5] Cutting, J. 2002. Pragmatics And Discourse. London: Rountledge

[6] Errington, J. 1998. Structure and style in Javanese: A semiotic view of linguistic etiquette. Philadelphia: The University of Pennsylvania Press.

[7] Fitriah., \& Hidayat, Didin Nuruddin. 2018. Politeness : Cultural Dimensions of Linguistic Choice. IJEE (Indonesian Journal of English Education), 5(1), 26-34 
[8] Handayani, Nur Vita. 2015. The Use of Expressive Speech Acts in Hannah Montana Session 1. REGISTER, Vol. 8, No. 1, June 2015

[9] Heriwati, S.H.2018. Expressive Speech Act : The Story Dewaruci Plays Work of Dalang Nartasabda.International Journal of Science and Research (IJSR), issn (Online): 2319-7064

[10] Junaidi, Muh. 2017. Politeness, Speech Act, and Discourse in Sasak Community. Mabasan, Vol. 11, No.1, Januari-Juni 2017: 1-17

[11] Kreidler, C.W. 1998. Introducing English Semantics. London: Rountledge

[12] Lanigan, R. 1977. Speech Act Phenomenology. The Hague: Martinus Nijhoff

[13] Leech, G. 1989. Principles of Pragmatics. London:Routledge

[14] Maskuri, K.D.S., Tarjana, Samiati., Djatmika., \& Purnanto, Dwi. 2019. Politeness Strategies in Directive Speech Acts in Local Indonesian Parliament Assembly Proceedings. International Journal of English Linguistics; Vol. 9 (3) 2019

[15] Mufiah, Nura Siti., \& Rahman, M.Y.N. 2018. SPEECH ACTS ANALYSIS OF DONALD TRUMP'S SPEECH. Professional Journal of English Education Volume 1, No.2, March 2018 pp $125-132$

[16] Mulyono, Slamet. 2016. Student's Expressive Politeness in The Interaction of Bahasa Indonesia Learning Process at MAN Kota Surakarta. Proceeding The 2nd International Conference on Teacher Training and Education Sebelas Maret University Volume 2 Number 12016 ISSN:25002-4124

[17] Mustofa, Ihyak., Nababan, M.R., \& Djatmika. 2019. Male Characters' Expressive Speech Act on Romantic Speech events in New Moon. International Journal of Linguistics, Literature and Translation ISSN: 2617-0299

[18] Navratilova, Olga Dontcheva. 2005. Politeness Strategies in Institutional Speech Acts. Discourse and Interaction 1 Brno Seminar on Linguistic Studies in English: Proceedings 2005. Masaryk University in Brno, 2005

[19] Nuryantiningsih, Farida., \& Pandanwangi, Wiekandini Dyah. 2018. Politeness and impoliteness in Javanese Speech Levels. Advances in Social Science, Education, and Humanities Research, Volume 166

[20] Poedjosoedarmo, S. 1979. Tingkat tutur bahasa Jawa (The speech levels of Javanese). Jakarta: Pusat Pembinaan dan Pengembangan Bahasa DEPDIKBUD (Centre for Language Development and Maintenance of The Department of Education and Culture).

[21] Rohali. 2018. Politeness Strategy of Directive Speech Act by Students-Lecturers of French Department FBS UNY. Advances in Social Science, Education and Humanities Research, volume 301 Seventh International Conference on Languages and Arts (ICLA 2018)

[22] Ronan, Patricia. 2015. Categorizing Expressive Speech Acts in The Pragmatically Annotated SPICE Ireland Corpus. ICAME Journal Volume 39, 2015

[23] Royanti .2019. Expressive Speech Act as Found on La La Land Movie. INOVISH JOURNAL, Vol. 4, No. 2, December 2019

[24] Searle, J. 1976. A Classification of Illocutioary Acts, 1-23

[25] Seviyani., \& Pujiati, Tri.2019. Expressive Speech Act in The Novel Dialogue The Perfect Husband. IDEAD Journal of Language Teaching and Learning, Linguistics and Literature Volume 7, Number 2, December 2019 pp.343-353

[26] Sukarno. 2010. The Reflection of the Javanese Cultural Concepts in the Politeness of Javanese. Kata Vol 12, Number 1, June 2010: 59-71

[27] Sukarno. 2015. Politeness Strategies in Responding to Compliments in Javanese. Indonesian journal of Applied Linguistics, Vol. 4 No. 2, January 2015, pp. 91-101

[28] Tamam, Badrut., Setiawan, Slamet., \& Anam, Syafi;ul. 2020. The Expressive Speech Act Used by Anies Rasyid Baswedan and Recep Tayyip Erdogan as the Reaction of the Attacts in Christchurch New Zealand. Prasasti: Journal of Linguistics, Vol.5, Number 1 April 2020

[29] Tauchid, Ahmad., \& Rukmini, Dwi. 2016. The Performance of Expressive Speech Acts as Found on Wayne Rooney's Facebook. English Education Journal 6(1) 2016

[30] Watts, Richard J. 2003. Politeness. Cambridge: Cambridge University Press 